Article

\title{
Electrodeposition of Ti-Doped Hierarchically Mesoporous Silica Microspheres/Tungsten Oxide Nanocrystallines Hybrid Films and Their Electrochromic Performance
}

\author{
Ya Song ${ }^{1}$, Zhiyu Zhang ${ }^{1}$, Lamei Yan ${ }^{2}$, Ling Zhang ${ }^{3}$, Simin Liu ${ }^{3}$, Shaowen Xie ${ }^{1,3}$, Lijian Xu ${ }^{3,4}$ \\ and Jingjing Du ${ }^{1,4, *}$ \\ 1 College of Packaging Materials and Engineering, Hunan University of Technology, Zhuzhou 412008, China; \\ sy18798448247@163.com (Y.S.); zzhiyu12@126.com (Z.Z.); 13502431554@163.com (S.X.) \\ 2 School of Digital Media and Design, Hangzhou Dianzi University, Hangzhou 310018, China; \\ ylm@hdu.edu.cn \\ 3 Hunan Key Laboratory of Biomedical Nanomaterials and Devices, College of Life Sciences and Chemistry, \\ Hunan University of Technology, Zhuzhou 412007, China; lingzhang645@126.com (L.Z.); \\ 18890229883@163.com (S.L.); xlj235@163.com (L.X.) \\ $4 \quad$ National \& Local Joint Engineering Research Center of Advanced Packaging Materials Developing \\ Technology, Hunan University of Technology, Zhuzhou 412008, China \\ * Correspondence: 10668@hut.edu.cn; Tel.: +86-181-5382-0923
}

Received: 4 November 2019; Accepted: 12 December 2019; Published: 17 December 2019

\begin{abstract}
In this paper, a novel Ti-doped hierarchically mesoporous silica microspheres/tungsten oxide (THMS/ $\mathrm{WO}_{3}$ ) hybrid film was prepared by simultaneous electrodeposition of Ti-doped hierarchically mesoporous silica microspheres (THMSs) and $\mathrm{WO}_{3}$ nanocrystallines onto the fluoride doped tin dioxide (FTO) coated glass substrate. It is demonstrated that the incorporation of THMSs resulted in the hybrid film with improved electrochromic property. Besides, the content of THMSs plays an important role on the electrochromic property of the hybrid film. An excellent electrochromic THMS/ $\mathrm{WO}_{3}$ hybrid film with good optical modulation $(52.00 \%$ at $700 \mathrm{~nm})$, high coloration efficiency $\left(88.84 \mathrm{~cm}^{2} \mathrm{C}^{-1}\right.$ at $\left.700 \mathrm{~nm}\right)$, and superior cycling stability can be prepared by keeping the weight ratio of $\mathrm{Na}_{2} \mathrm{WO}_{4} \cdot 2 \mathrm{H}_{2} \mathrm{O}$ (precursor of $\mathrm{WO}_{3}$ ):THMSs at 15:1. The outstanding electrochromic performances of the THMS/ $\mathrm{WO}_{3}$ hybrid film were mainly attributed to the porous structure, which facilitates the charge-transfer, promotes the electrolyte infiltration and alleviates the expansion of the film during $\mathrm{Li}^{+}$ insertion. This kind of porous $\mathrm{THMS} / \mathrm{WO}_{3}$ hybrid film is promising for a wide range of applications in smart homes, green buildings, airplanes, and automobiles.
\end{abstract}

Keywords: Ti-doped hierarchically mesoporous silica; electrochromic; electrodeposition; tungsten oxide; hybrid film

\section{Introduction}

Electrochromic materials that can reversibly change their optical properties such as transmittance [1], reflectance [2] and absorption [3] at the stimulation of a small electric field, have received significant interests owing to their potential applications in energy-saving smart windows [4-6], non-emissive information displays [7,8] and antiglare automotive mirrors [9]. It is recognized that the mechanism of the dynamic which changed optical properties of the electrochromic materials is mainly attributed to the electrochemically induced oxidation-reduction reaction [10,11]. Generally, materials containing variable valence elements can be used as electrochromic materials, including conducting polymers [12-14], organic small molecular [15,16] and inorganic metal oxides [17-20]. 
Among all the electrochromic materials, tungsten oxide $\left(\mathrm{WO}_{3}\right)$ as a popular-star electrochromic material has been broadly explored due to its high optical contrast and a relatively low production cost [21-23], as compared with other electrochromic materials. Besides, the $\mathrm{WO}_{3}$ electrochromic material can control the spectral response of electrochromic in the visible spectrum and the infrared (IR) region, which has great application in architecture, aerospace, information storage and artificial intelligence fields. It is generally accepted that the electrochromic phenomena of tungsten oxide are attributed to the injection/extraction of electrons and cations $\left(\mathrm{H}^{+}, \mathrm{Li}^{+}\right)$, which promote the redox reaction of $\mathrm{W}^{6+} \leftrightarrow \mathrm{W}^{5+}$, and resulted in a reversibly color change of transparent $\leftrightarrow$ blue [24-26]. More et al. [27] have reported the preparation of $\mathrm{WO}_{3}$ electrochromic films by electrodeposition and the resultant $\mathrm{WO}_{3}$ film exhibited amorphous nature, closed packed nano-granular morphology, good coloration efficiency and visible high transmittance. However, unsatisfactory optical modulation [28], long switching time [29] and short life time limit [30] its electrochromic effectiveness. To overcome these obstacles, significant efforts have been made to synthesis of porous $\mathrm{WO}_{3}$ electrochromic films to enhance its electrochromic performance. For instance, Xie and coworkers [31] prepared the two-dimensional (2D) grid structured $\mathrm{WO}_{3}$ film using polystyrene nanofibers as sacrificial templates to achieve an enhancement of electrochromic performance. The enhanced electrochromic performance may be attributed to that of a porous structure facilitating the penetration of electrolytes onto the $\mathrm{WO}_{3}$ framework and shortening the ionic diffusion paths for lithium ions in porous films. Zhang et al. [32] presented a periodical bowl-like macroporous $\mathrm{WO}_{3}$ array film synthesized by using the assembled monolayer polystyrene spheres as a template. The resultant $\mathrm{WO}_{3}$ microbowl array film showed superior electrochromic property with coloration efficiency of $68 \mathrm{~cm}^{2} \mathrm{C}^{-1}$, response times of $3.6 \mathrm{~s}$ (coloration) and $1.0 \mathrm{~s}$ (bleaching) in comparison with the dense film prepared without a PS template. Compared with the template method, simultaneous electrodeposition of $\mathrm{WO}_{3}$ and other nanomaterials for fabrication of composite $\mathrm{WO}_{3}$ film is more convenient and efficient in creation of a porous structure in $\mathrm{WO}_{3}$ film [33-35]. Song et al. [36] reported the fabrication of porous $\mathrm{WO}_{3}$ film by electrochemically polymerizing 3-chlorothiophene on the surface of $\mathrm{WO}_{3}$ film in the ionic liquid 1-butyl-3-metyllimidazolium hexafluorophosphate. Fu et al. [37] described the electrochemical deposition of amorphous $\mathrm{WO}_{3}$ nanocrystallines/electrochemical reduced graphene oxide $\left(\mathrm{WO}_{3} / \mathrm{rGO}\right)$ nanocomposite film. The electrochromic properties of the $\mathrm{WO}_{3} / \mathrm{rGO}$ film show significant improvement compared to $\mathrm{WO}_{3}$ films, which is mainly due to the synergistic incorporation of $\mathrm{rGO}$ into $\mathrm{WO}_{3}$. Cai et al. [38] have prepared $\mathrm{TiO}_{2} @ \mathrm{WO}_{3}$ core/shell nanorod array composites by the combination of hydrothermal and electrodeposition method. The array films show remarkable enhancement of the electrochromic properties stemming from the core/shell structure and the porous space among the nanorod array.

Recently, there has been great interest in Ti-doped $\mathrm{WO}_{3}$ thin films because the addition of adequate dopant in $\mathrm{WO}_{3}$ not only modifies its structure but also improves the electrochromic performance. Acosta's group [39] has employed a pulsed spray pyrolysis technique to fabricate $\mathrm{Ti}-\mathrm{WO}_{3}$ thin films with improved electrochromic behavior. Karuppasamy [40] proved that the Ti-doped $\mathrm{WO}_{3}$ thin films prepared by co-sputtering titanium and tungsten in $\mathrm{Ar}+\mathrm{O}_{2}$ atmosphere, which exhibited high optical modulation and coloration efficiency. Barawi et al. [41] presented a dual-band electrochromic device with high optical contrast based on the $\mathrm{TiO}_{2} / \mathrm{V}_{2} \mathrm{O}_{5} / / \mathrm{WO}_{3}$ composite materials and the device was capable of selectively controlling the transmitted sunlight over the visible and the near-infrared regions. Cai et al. [42] introduced a template-free hydrothermal method for preparation of hierarchical structure Ti-doped $\mathrm{WO}_{3}$ thin films with enhanced electrochromic performance.

Herein, we reported the preparation of Ti-doped hierarchically mesoporous silica microspheres/tungsten oxide (THMS/ $\left.\mathrm{WO}_{3}\right)$ hybrid film by simultaneous electrodeposition of Ti-doped hierarchically mesoporous silica microspheres (THMSs) and $\mathrm{WO}_{3}$ nanocrystallines onto the fluoride doped tin dioxide (FTO) coated glass substrate. The effect of the incorporation of THMSs in $\mathrm{WO}_{3}$ films on structure, morphology and electrochromic properties of $\mathrm{WO}_{3}$ films were investigated. Besides, the relationship between the structure and electrochromic properties including the electrochemical properties of the $\mathrm{CV}$ behavior, electric resistance and ion diffusion efficiency, and optical properties 
of transmittance modulation range, switching time, coloration efficiency and cycling stability of $\mathrm{THMS} / \mathrm{WO}_{3}$ hybrid film was systematically evaluated.

\section{Experimental Sections}

\subsection{Materials}

Hexadecylpyridinium chloride (CPC), 4-nitrophenol, tetraethoxysilane (TEOS), ammonia solution $(25 \mathrm{wt} \%)$, titanium oxysulfate hydrate $\left(\mathrm{TiOSO}_{4} \cdot \mathrm{nH}_{2} \mathrm{O}\right)$ and hydrogen peroxide solution $\left(\mathrm{H}_{2} \mathrm{O}_{2}, 30 \mathrm{wt} \%\right)$, were purchased from Aladdin (Aladdin, Beijing, China). Poly (acrylic acid) (PAA, $M_{\mathrm{w}}=240,000 \mathrm{~g} / \mathrm{mol}$ ) in water $(25 \mathrm{wt} \%)$, propylene carbonate (PC, 99.5\%) was obtained from Acros (Acros, Shanghai, China). Sodium tungstate dihydrate $\left(\mathrm{Na}_{2} \mathrm{WO}_{4} \cdot 2 \mathrm{H}_{2} \mathrm{O}, 99 \%\right)$ and lithium perchlorate $(99 \%)$ was obtained from Innochem (Innochem, Beijing, China). The fluorine-doped tin oxide (FTO) glasses with a thickness of $2.2 \mathrm{~mm}$ were purchased from Yaoke Photoelectric Co., Ltd. (Yaoke Photoelectric Co., Ltd., Huaian, China) THMSs were synthesized by dynamic template method, employing the mesomorphous complexes of cationic surfactant $\mathrm{CPC}$ and anionic polyelectrolyte $\mathrm{PAA}$ as template, $\mathrm{TiOSO}_{4}$ as titanium source and TEOS as silica source, as discussed elsewhere [43-45]. HMSs were prepared with the similar method without adding of $\mathrm{TiOSO}_{4}$. All the chemical agents were used without further purification.

\subsection{Fabrication of Porous $\mathrm{THMS}_{\mathrm{W}} \mathrm{WO}_{3}$ Hybrid Films}

Porous THMS $/ \mathrm{WO}_{3}$ hybrid films were fabricated by electrochemical deposition performed on an CHI440C electrochemical workstation at room temperature using a three-electrode system, where a Pt sheet $\left(2 \mathrm{~cm}^{2}\right)$ was used as the counter electrode and $\mathrm{Ag} / \mathrm{AgCl}$ (in $3 \mathrm{M} \mathrm{KCl}$ aqueous solution) as the reference electrode, and FTO-coated glass substrate as work electrode. Initially, the FTO were sequentially sonicated in DI water, $0.1 \mathrm{M} \mathrm{HCl}$ solution and ethanol for $15 \mathrm{~min}$, respectively, and then dried with $\mathrm{N}_{2}$ before usage. The peroxo tungstic acid (PTA) solution was prepared by dissolving $6 \mathrm{mmol}$ $(1.98 \mathrm{~g}) \mathrm{Na}_{2} \mathrm{WO}_{4} \cdot 2 \mathrm{H}_{2} \mathrm{O}$ in $100 \mathrm{~mL}$ deionized water with stirring at room temperature for $2 \mathrm{~h}$, followed by adding of $2.8 \mathrm{~mL} \mathrm{H}_{2} \mathrm{O}_{2}$ and $1.2 \mathrm{~mL} \mathrm{HNO}_{3}$. After that, certain amounts $(0.10 \mathrm{~g}-0.40 \mathrm{~g})$ of THMSs were added into PTA solution under stirring. The THMS/ $\mathrm{WO}_{3}$ hybrid films were electrodeposited onto FTO-coated glass substrate from the precursor solution at a constant potential of $-0.47 \mathrm{~V}$ for $25 \mathrm{~min}$. The as-deposited THMS/ $\mathrm{WO}_{3}$ hybrid film was rinsed with DI water and then dried in air at room temperature for $2 \mathrm{~h}$. By keeping the weight ratio of $\mathrm{Na}_{2} \mathrm{WO}_{4} \cdot 2 \mathrm{H}_{2} \mathrm{O}$ :THMSs at 20:1, 15:1, 10:1 and $5: 1$, four THMS $/ \mathrm{WO}_{3}$ hybrid films were prepared. The hybrid films were named as THMS $/ 20 \mathrm{WO}_{3}$, THMS $/ 15 \mathrm{WO}_{3}, \mathrm{THMS} / 10 \mathrm{WO}_{3}$, and THMS $/ 5 \mathrm{WO}_{3}$, respectively. The pure $\mathrm{WO}_{3}$ film was prepared by the similar method without adding of THMSs. Another reference hybrid film of $\mathrm{HMSs} / 15 \mathrm{WO}_{3}$ was also prepared by electrochemical deposition by the adding of HMSs in the PTA solution, and the weight ratio of $\mathrm{Na}_{2} \mathrm{WO}_{4} \cdot 2 \mathrm{H}_{2} \mathrm{O}: \mathrm{HMSs}$ was kept at 15:1.

\subsection{Electrochemical Characterization}

The cyclic voltammetry (CV) and chronoamperometry (CA) measurements were performed in a three-compartment system containing $1 \mathrm{M}$ lithium perchlorate/propylene carbonate $\left(\mathrm{LiClO}_{4} / \mathrm{PC}\right)$ as electrolyte, $\mathrm{Ag} / \mathrm{AgCl}$ as a reference electrode and $\mathrm{Pt}$ foil as the counter electrode. The voltage supply was from CHI440C electrochemical workstation. Electrochemical impedance spectroscopy (EIS) tests were conducted on this electrochemical workstation with a superimposed $5 \mathrm{mV}$ sinusoidal voltage in the frequency range of $0.05 \mathrm{~Hz}-100 \mathrm{kHz}$. The spectro-electrochemical properties of the films were measured using a CHI440C (CH Instruments, Inc., Austin, Texas, USA) and a UV-Vis-NIR spectrophotometer (UV-3600PLUS220/230VC, Shimadzu, Kyoto, Japan). The transmission spectra of the films were recorded in the wavelength range of 300-1600 $\mathrm{nm}$ at potentials of $-1 \mathrm{~V}$ and $1 \mathrm{~V}$. The situ transmission spectra $(700 \mathrm{~nm})$ of films under continuous double potentiostatic measurements between $-1 \mathrm{~V}$ and $1 \mathrm{~V}$ with at time interval of $40 \mathrm{~s}$ were measured by combination of a Shimadzu 
UV-3600PLUS220/230VC spectrophotometer and CHI440C electrochemical workstation. The coloration efficiencies of the electrochromic films were measured according to the methods reported by Li et al. [46].

\subsection{Sample Characterization}

Scanning electron microscopy (SEM) images were obtained with TESCAN MIRA3 LMU instrument (TESCAN, Brno, Czech Republic). X-ray diffraction (XRD) using a Rigaku Model D/max-2500 (Rigaku Corporation, Tokyo, Japan) diffractometer, with $\mathrm{Cu} \mathrm{K} \alpha$ radiation in the $2 \theta$ range of $10-80^{\circ}$ with a step size of $0.02^{\circ}$. Transmission electron microscopy (TEM) observations and elemental analysis for Si/Ti ratios were performed on a JEM-1011 (JEOL, Tokyo, Japan) electron microscope, working at $100 \mathrm{kV}$, whereby a small drop of the sample was deposited onto a carbon-coating copper grid and dried at room temperature under atmospheric pressure. X-ray photoelectron spectroscopy (XPS) spectra were obtained with a Thermo Fisher ESCALAB 250Xi (Thermo Fisher Scientific, Waltham, MA, USA) system, using a monochromatic $\mathrm{Al} \mathrm{K \alpha}$ X-ray source.

\section{Results and Discussion}

The THMS $/ \mathrm{WO}_{3}$ hybrid films were prepared by a simple in situ electrodeposition process. Initially, THMSs were synthesized by the "dynamic template" method employing the mesomorphous complex of CPC and PAA as template, TEOS as silica source and $\mathrm{TiOSO}_{4}$ as titanium source. Subsequently, the deposition of THMS/ $\mathrm{WO}_{3}$ hybrid films onto the FTO-coated glass substrate were achieved by electrochemical deposition of the precursor solution containing $\mathrm{Na}_{2} \mathrm{WO}_{4} \cdot 2 \mathrm{H}_{2} \mathrm{O}$ and THMSs in a three-electrode system, where a Pt sheet as the counter electrode, $\mathrm{Ag} / \mathrm{AgCl}$ as the reference electrode, and FTO-coated glass substrate as work electrode. Finally, the electrochromic properties of the $\mathrm{THMS} / \mathrm{WO}_{3}$ hybrid films were studied by stepping the voltages between $-1 \mathrm{~V}$ (deep blue) and $1 \mathrm{~V}$ (transparent). The whole preparation procedure was schematically shown in Scheme 1.

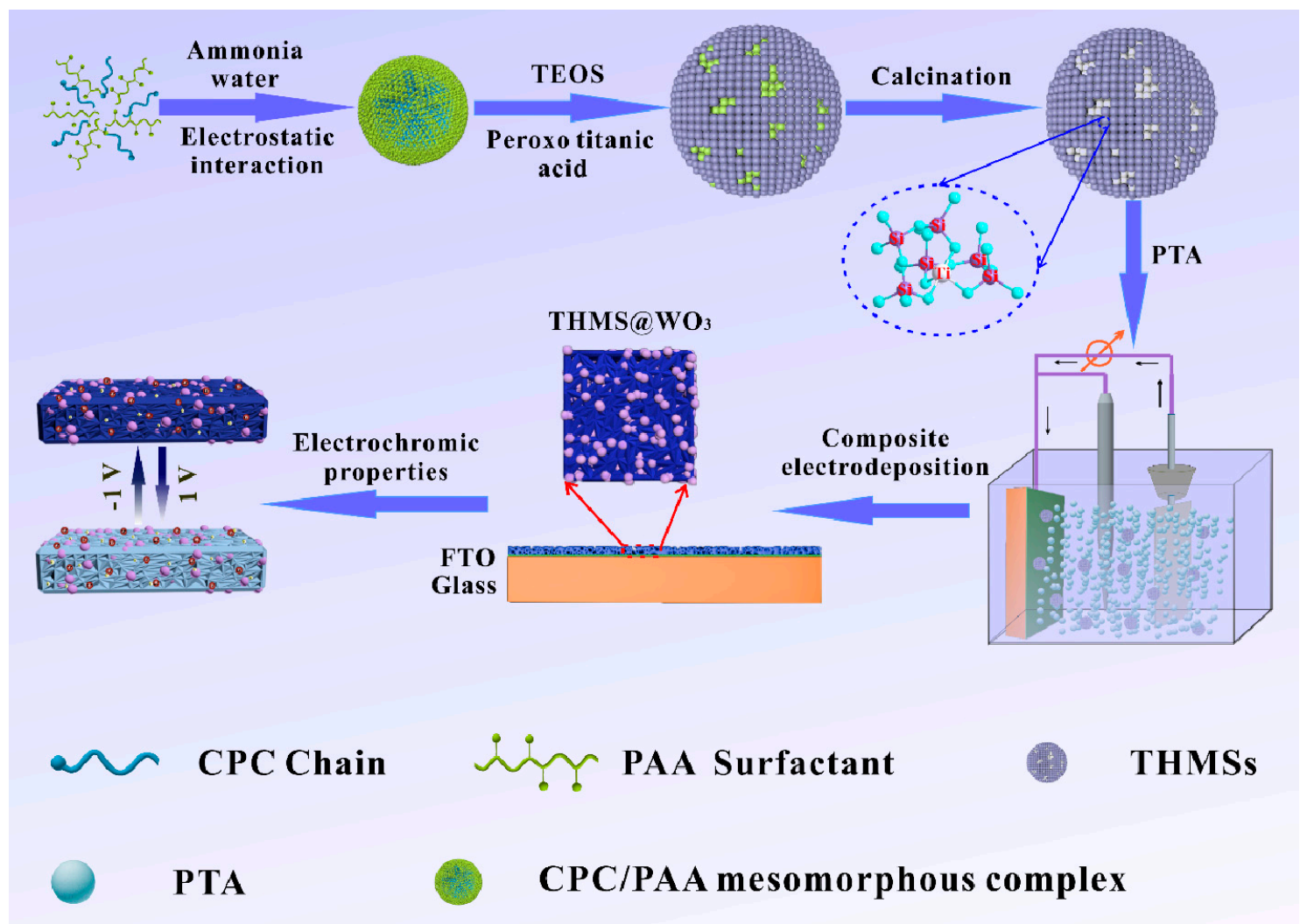

Scheme 1. Schematic illustration of the fabrication and electrochromic property of the Ti-doped hierarchically mesoporous silica microspheres/tungsten oxide $\left(\mathrm{THMS} / \mathrm{WO}_{3}\right)$ hybrid films. 


\subsection{Synthesis of Ti-Doped Hierarchically Mesoporous Silica Microspheres (THMSs)}

Figure 1 showed the SEM, TEM and the TEM elemental mapping of the synthesized THMSs. As shown in the SEM image (Figure 1A), the synthesized THMSs was uniform with average diameter of $\sim 500 \mathrm{~nm}$. From the SEM image at high magnification (the inset of Figure 1A), it was found that the surface of the THMSs was rough and contained obvious pores. TEM images gave a more deep insight of the porous structure of the THMSs. As shown in Figure 1B, hierarchically porous structure with plenty of mesopores and interstitial pores throughout the entire particle of the THMSs were clearly observed. The high resolution TEM image (Figure 1C) showed that the mesopores with pore size of approximately 2-3 nm in THMSs were in highly periodic order. Besides, the interstitial pores were well co-existed in THMSs, without disturbing the ordering of the mesopores. The elemental composition of the THMSs was checked by TEM elemental mapping. As shown in Figure 1D-F, the elements including $\mathrm{O}, \mathrm{Si}$, Ti were detected and found to be homogenously distributed in THMSs. The elemental content of Ti was measured to be $2.56 \%$ by EDXS (Supplementary Materials Figure S1).
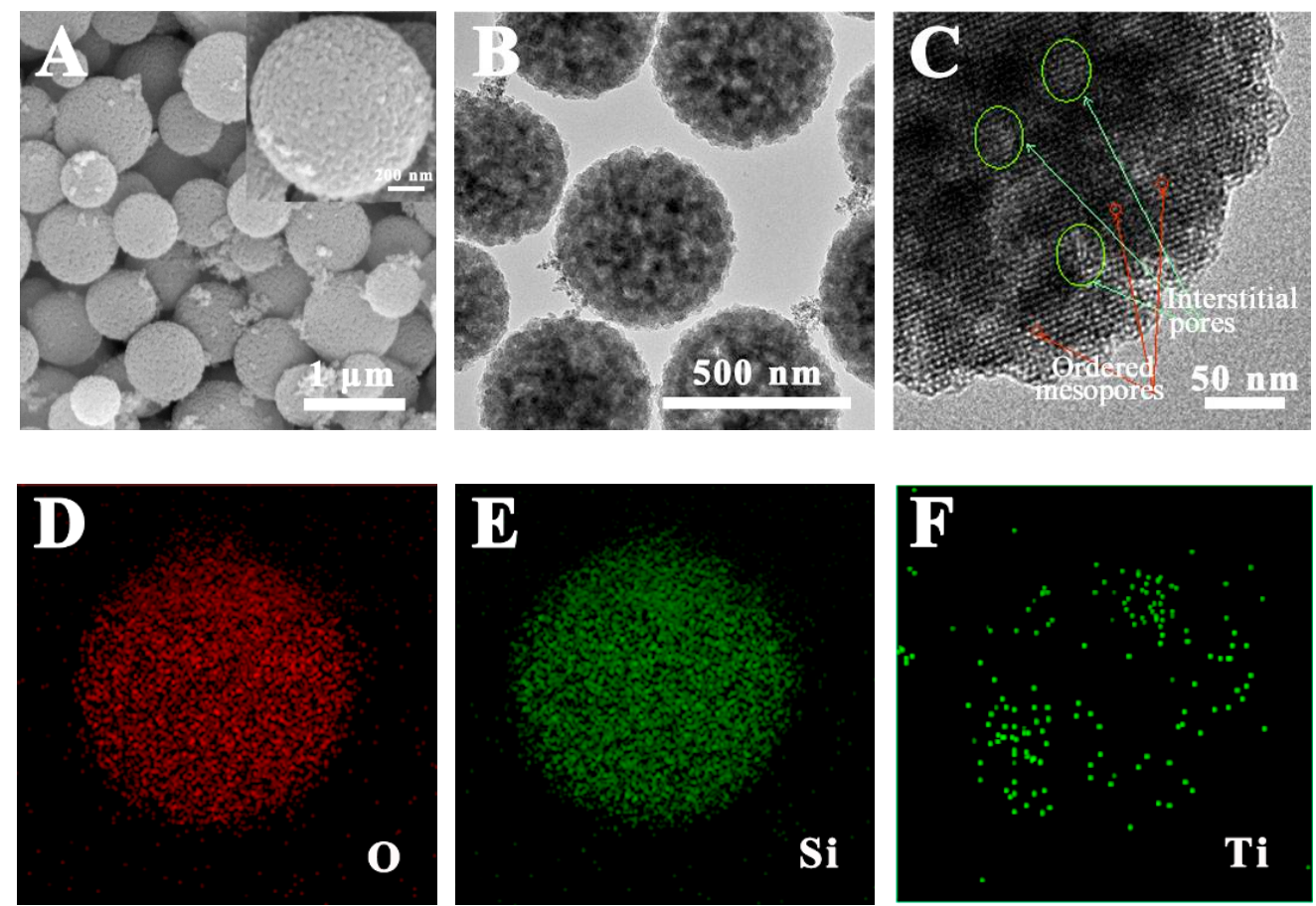

Figure 1. SEM (A) and TEM images of THMSs (B,C), and element mapping images of O (D), Si (E) and $\mathrm{Ti}(\mathbf{F})$ in the THMSs.

\subsection{Fabrication of $\mathrm{THMS} / \mathrm{WO}_{3} \mathrm{Hybrid}$ Films}

The THMS $/ \mathrm{WO}_{3}$ hybrid films were prepared by simultaneous electrodeposition of the THMSs and $\mathrm{WO}_{3}$ onto the FTO-coated glass substrate. The ratio of $\mathrm{Na}_{2} \mathrm{WO}_{4} \cdot 2 \mathrm{H}_{2} \mathrm{O}$ and THMSs had a great impact on the morphology of the synthesized THMS/ $\mathrm{WO}_{3}$ hybrid films. Here, we take the $\mathrm{THMS} / 15 \mathrm{WO}$ sample prepared with the weight ratio of $\mathrm{Na}_{2} \mathrm{WO}_{4} \cdot 2 \mathrm{H}_{2} \mathrm{O}$ :THMSs at $15: 1$, as a typical example to study the physical properties of the synthesized THMS/WO 3 hybrid films. Figure 2 shows the XRD patterns of the FTO-coated glass substrate (FTO film), pure $\mathrm{WO}_{3}$ deposit onto the FTO-coated glass substrate $\left(\mathrm{WO}_{3}\right.$ film), and $\mathrm{THMS} / 15 \mathrm{WO}_{3}$ film, with the standard cubic phase $\mathrm{SnO}_{2}$ as a reference. As shown, the XRD pattern of the FTO film was resembled as that of the standard pattern of cubic phase $\mathrm{SnO}_{2}$ (JCPDS No.41-1445). For comparison, we prepared the pure $\mathrm{WO}_{3}$ film by electrodeposition of pure $\mathrm{WO}_{3}$ on the FTO-coated glass substrate. The XRD pattern of pure $\mathrm{WO}_{3}$ film displayed not only the sharp peaks corresponded to the cubic phase $\mathrm{SnO}_{2}$, but also an additional broadened peak around $2 \theta \approx 26.62^{\circ}$. The additional peak was corresponded to the amorphous $\mathrm{WO}_{3}$. The XRD pattern of 
THMS $/ 15 \mathrm{WO}_{3}$ film was similar to that of the $\mathrm{WO}_{3}$ film, indicating that the incorporation of THMSs did not significantly change the amorphous nature of the $\mathrm{WO}_{3}$. In general, nanocrystallines $\mathrm{WO}_{3}$ with amorphous background are suitable for electrochromic applications since it is favorable for ions to diffuse through.

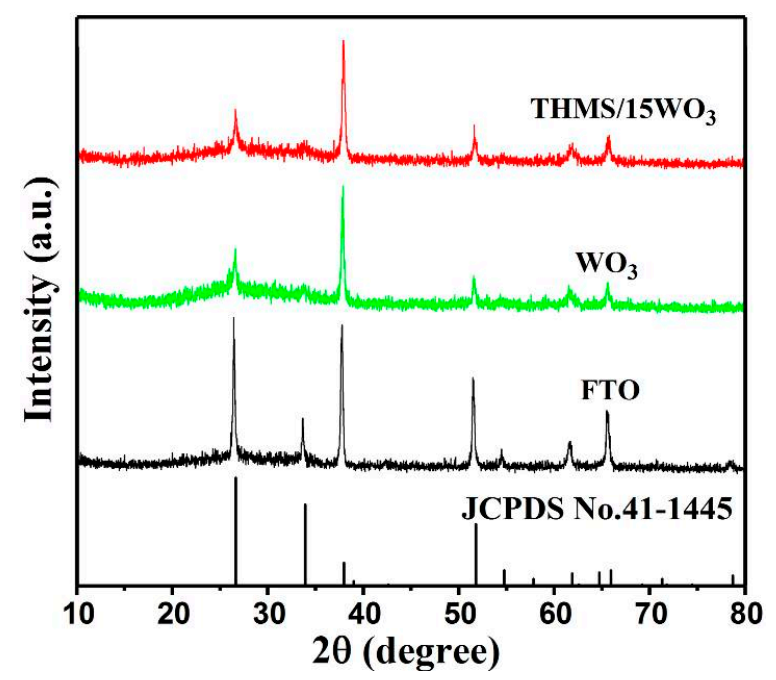

Figure 2. The XRD patterns of the FTO-coated glass substrate (FTO film), pure $\mathrm{WO}_{3}$ deposition onto the FTO-coated glass substrate $\left(\mathrm{WO}_{3}\right.$ film), and $\mathrm{THMS} / 15 \mathrm{WO}_{3}$ film, with the standard cubic phase $\mathrm{SnO}_{2}$ as a reference.

The morphology of the as-prepared $\mathrm{WO}_{3}$ and $\mathrm{THMS} / 15 \mathrm{WO}_{3}$ hybrid films were further compared by SEM observation. As shown, the pure $\mathrm{WO}_{3}$ film was compact and composed of $\mathrm{WO}_{3}$ nanocrystallines (Figure 3A,B). Differently, the THMS/15 $\mathrm{WO}_{3}$ film was much rougher with obviously porous structure, as shown in Figure $3 \mathrm{C}$. The THMS $/ 15 \mathrm{WO}_{3}$ film was composed of $\mathrm{WO}_{3}$ nanocrystallines and THMSs as indicated by the blue stained part. The magnified SEM image (Figure 3D) further demonstrated the existence of the THMSs, indicating the successful fabrication of $\mathrm{THMS} / \mathrm{WO}_{3}$ hybrid film.
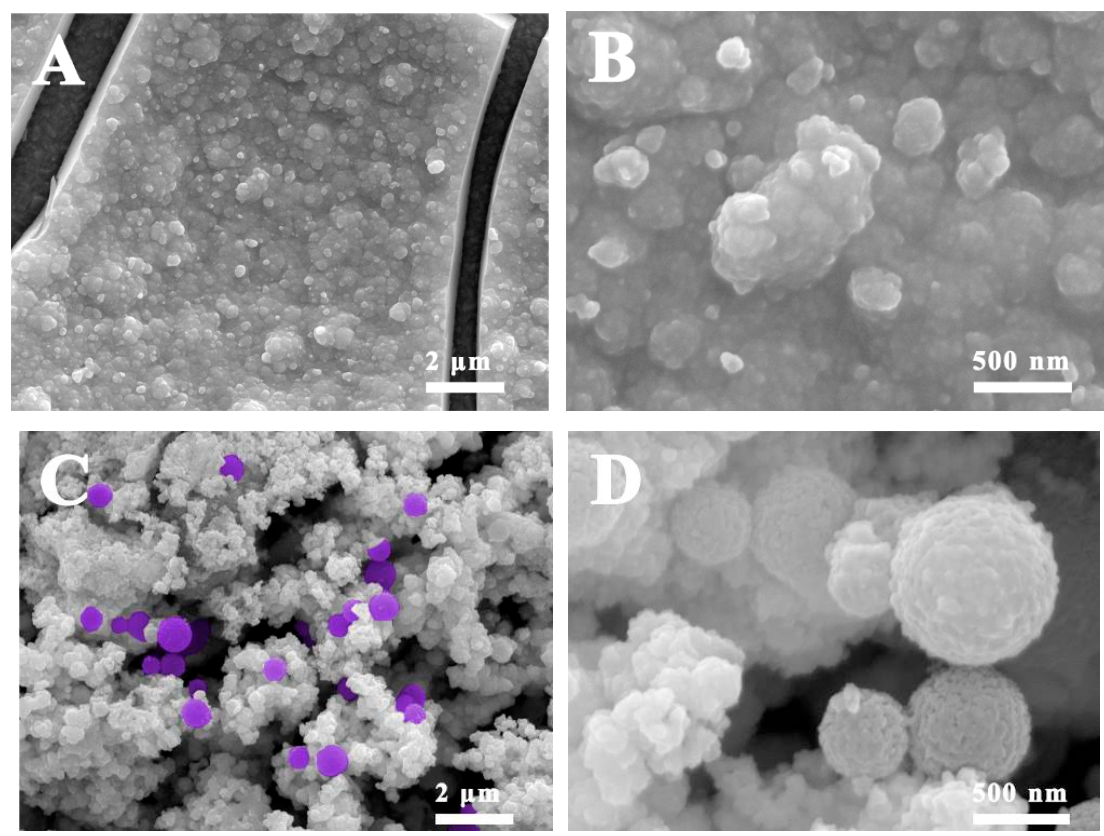

Figure 3. The SEM images of pure $\mathrm{WO}_{3}(\mathbf{A}, \mathbf{B})$ and $\mathrm{THMS} / 15 \mathrm{WO}_{3}$ film $(\mathbf{C}, \mathbf{D})$ at different magnifications. 
X-ray photoelectron spectroscopy (XPS) measurements [47] were performed to analyze the surface elemental composition and the valence state of the main elements in the THMS $/ \mathrm{WO}_{3}$ films. The XPS survey spectrum of $\mathrm{THMS} / 15 \mathrm{WO}_{3}$ film showed that the hybrid film contains $\mathrm{C}, \mathrm{W}, \mathrm{O}$, elements since the peaks at specific binding energy of $285.00 \mathrm{eV}, 36.12 \mathrm{eV}$, and $531.00 \mathrm{eV}$ were successfully detected, as shown in Figure 4a. The high-resolution W 4f core-level XPS spectrum was shown in Figure 4b. The spin-orbit doublets in this spectrum corresponding to $\mathrm{W}(\mathrm{VI}) 4 \mathrm{f}_{7 / 2}, \mathrm{~W}$ (VI) $4 \mathrm{f}_{5 / 2}$ and $\mathrm{W}$ (VI) $5 \mathrm{p}_{3 / 2}$ peaks located at $36.19 \mathrm{eV}, 38.30 \mathrm{eV}$ and $42.20 \mathrm{eV}$ were clearly observed, indicating that $\mathrm{W}$ was at its highest oxidation state $\left(\mathrm{W}^{6+}\right)$ [48]. The Ti $2 \mathrm{p}$ and Si $2 \mathrm{p}$ peaks were not well resolved due to the low content of THMSs in THMS $/ 15 \mathrm{WO}_{3}$ film. However, it can be clearly resolved in the high-resolution XPS spectrum. The existence of Ti element in THMS $/ 15 \mathrm{WO}_{3}$ film was demonstrated by the high-resolution XPS spectrum at the range of $469 \mathrm{eV}$ to $453 \mathrm{eV}$, as shown in Figure 4c. Besides, the Ti $2 \mathrm{p}_{3 / 2}$ and Ti $2 \mathrm{p}_{1 / 2}$ peaks were located at $458.6 \mathrm{eV}$ and $464.3 \mathrm{eV}$ in the Ti $2 \mathrm{p}$ spectrum, verifying that the $\mathrm{Ti}$ in the THMS $/ 15 \mathrm{WO}_{3}$ film was in the highest oxidation state $\left(\mathrm{Ti}^{4+}\right)$. Moreover, the high-resolution XPS spectrum at the range of $111 \mathrm{eV}$ to $96 \mathrm{eV}$ showed an obvious Si 2p (Figure 4d) peak at $104.18 \mathrm{eV}$, demonstrating that the $\mathrm{THMS} / 15 \mathrm{WO}_{3}$ film contains $\mathrm{Si}$ element.
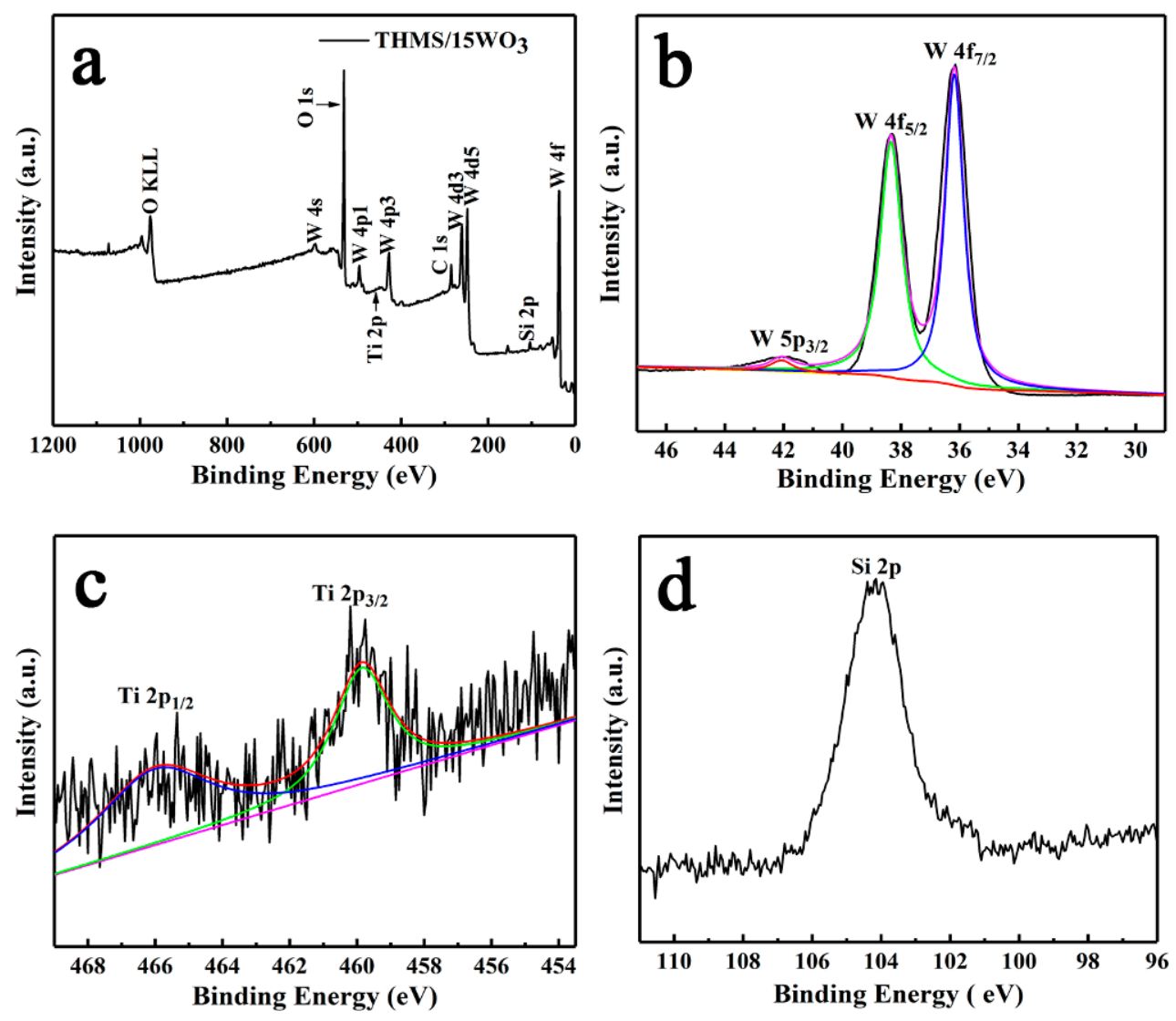

Figure 4. (a) XPS survey spectra of the THMS $/ 15 \mathrm{WO}_{3}$ film, (b) the high-resolution $\mathrm{W} 4 \mathrm{f}$ core-level XPS spectrum, (c) Ti $2 \mathrm{p}$ spectrum at the range of $469 \mathrm{eV}$ to $453 \mathrm{eV}$ and (d) Si $2 \mathrm{p}$ at the range of $111 \mathrm{eV}$ to $96 \mathrm{eV}$.

By varying the weight ratio of $\mathrm{Na}_{2} \mathrm{WO}_{4} \cdot 2 \mathrm{H}_{2} \mathrm{O}$ :THMSs in the precursor solution, we prepared a series of THMS/ $/ \mathrm{WO}_{3}$ hybrid films with the weight ratio of $\mathrm{Na}_{2} \mathrm{WO}_{4} \cdot 2 \mathrm{H}_{2} \mathrm{O}$ :THMSs at 20:1, 15:1, 10:1, and 5:1, respectively. The resultant THMS/ $\mathrm{WO}_{3}$ hybrid films were denoted as THMS $/ 20 \mathrm{WO}_{3}$, THMS $/ 15 \mathrm{WO}_{3}, \mathrm{THMS} / 10 \mathrm{WO}_{3}$ and THMS $/ 5 \mathrm{WO}_{3}$, respectively. The morphology of the resultant THMS $/ \mathrm{WO}_{3}$ hybrid films were observed by SEM. As shown in Figure 5, THMS $/ 20 \mathrm{WO}_{3}$ (Figure $5 \mathrm{~A}, \mathrm{~B}$ ) and THMS $/ 10 \mathrm{WO}_{3}$ (Figure $5 \mathrm{C}, \mathrm{D}$ ) hybrid films exhibited a rough surface with obviously porous structure and both the $\mathrm{WO}_{3}$ nanocrystallines and THMSs were clearly seen (the blue stained part). 
The morphology is similar to that of the $\mathrm{THMS} / 15 \mathrm{WO}_{3}$ hybrid films (Figure $3 \mathrm{C}, \mathrm{D}$ ). Differently, the amount of the deposited THMSs on the $\mathrm{THMS} / \mathrm{WO}_{3}$ hybrid films increased with decreasing the weight ratio of $\mathrm{Na}_{2} \mathrm{WO}_{4} \cdot 2 \mathrm{H}_{2} \mathrm{O}$ :THMSs. The SEM images of the THMS/5WO 3 hybrid films were shown in Figure 5E,F. As shown, very few $\mathrm{WO}_{3}$ nanocrystallines and THMSs were deposited on the hybrid film. This may be due to the poor electrical conductivity of the THMSs than that of $\mathrm{WO}_{3}$ nanocrystallines. Too many THMSs in the precursor solution prevented the deposition of $\mathrm{WO}_{3}$ nanocrystallines and THMSs onto the FTO glass substrate.
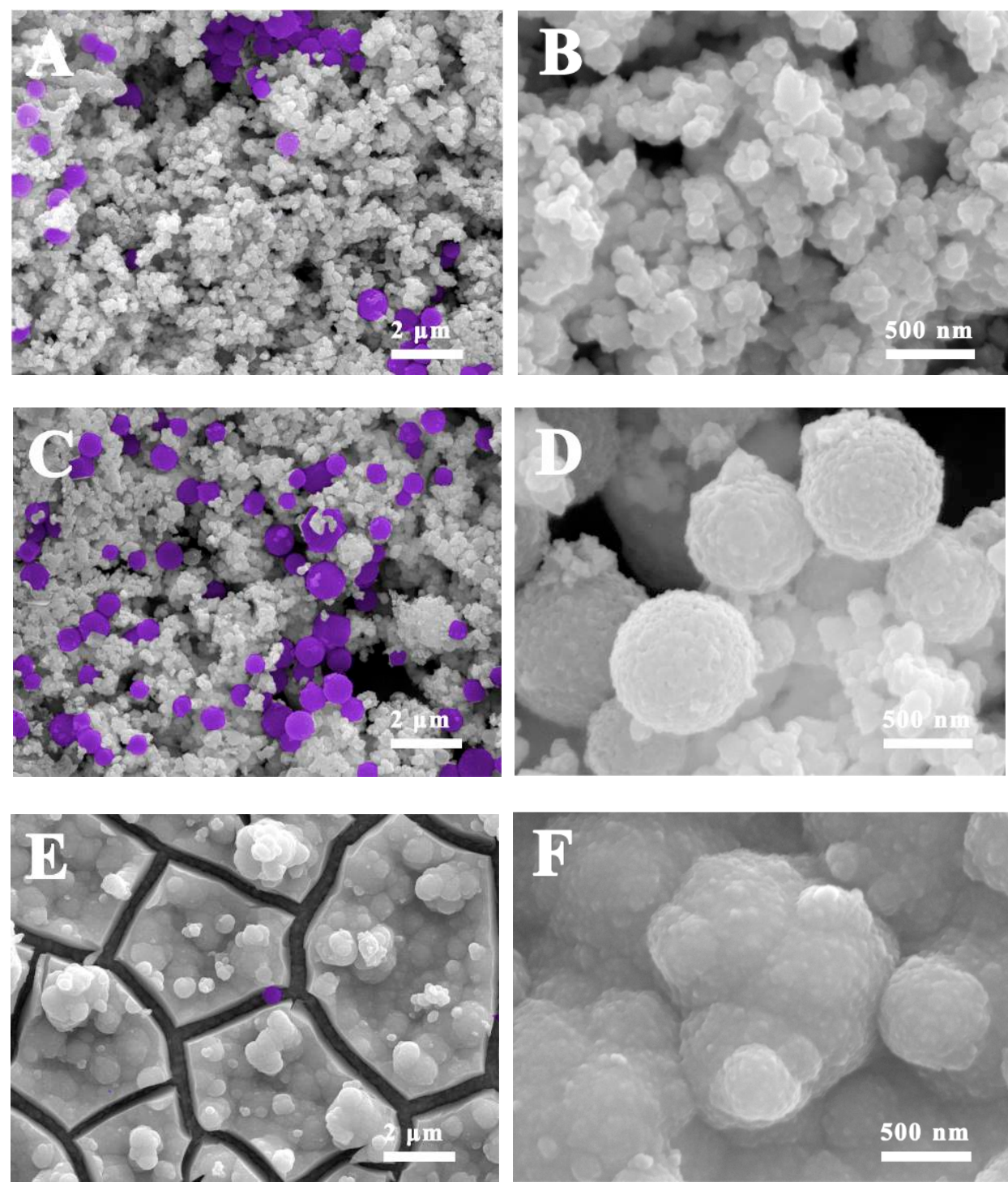

Figure 5. The SEM images of $\mathrm{THMS}_{2} 20 \mathrm{WO}_{3}(\mathbf{A}, \mathbf{B}), \mathrm{THMS} / 10 \mathrm{WO}_{3}(\mathbf{C}, \mathbf{D})$ and $\mathrm{THMS} / 5 \mathrm{WO}_{3}(\mathbf{E}, \mathbf{F})$ hybrid films.

\subsection{Electrochromic Properties of $\mathrm{THMS} / \mathrm{WO}_{3}$ Hybrid Films}

\subsubsection{Electrochemical Performances}

In order to check the effect of THMSs incorporation on the electrochemical performances of the $\mathrm{WO}_{3}$ film, the $\mathrm{CV}$ behavior of the $\mathrm{WO}_{3}$ and $\mathrm{THMS} / \mathrm{WO}_{3}$ hybrid films with different THMSs content were comparatively studied in a standard three-electrode system. The CV curves of the five films were measured in the potential region of $-1 \mathrm{~V} \sim 1 \mathrm{~V}$ at a scan rate of $50 \mathrm{mV} \mathrm{s}^{-1}$. The $\mathrm{CV}$ curves of the five films exhibited some observable similarities and differences, as shown in Figure 6a. At first glance, the shapes 
of the CV curves were similar for all the films. Nevertheless, the enclosed area of the CV curves was different from each other. Generally, the area of the CV curves indicates the amount of charges inserted or extracted from the samples, which corresponded to the electrochemical performance of the materials. After careful observation, we found that the enclosed area of the CV curves was correlated with the content of THMSs. With the decreasing of the weight ratio of $\mathrm{Na}_{2} \mathrm{WO}_{4} \cdot 2 \mathrm{H}_{2} \mathrm{O}: \mathrm{THMSs}$, which means increasing the content of THMSs in composite film, the area of the CV curves was initially increased with the weight ratio of $\mathrm{Na}_{2} \mathrm{WO}_{4} \cdot 2 \mathrm{H}_{2} \mathrm{O}$ :THMSs beyond 15:1 and then decreased. Clearly, the $\mathrm{CV}$ curves of the THMS $/ 15 \mathrm{WO}_{3}$ film exhibited the largest enclose area. This may be due to that the $\mathrm{THMS} / 15 \mathrm{WO}_{3}$ film had the largest surface area as indicated by the obviously porous surface structure. The large surface area facilitated the insertion/extraction of small ions ( $\left.\mathrm{Li}^{+}\right)$into the host lattice. Besides, the doping of $\mathrm{Ti}^{4+}$ can increase the conductivity of the hybrid film. This can be demonstrated by the comparison of the $\mathrm{CV}$ curves of the $\mathrm{THMS} / 15 \mathrm{WO}_{3}$ and $\mathrm{HMS} / 15 \mathrm{WO}_{3}$ films, as shown in Supplementary Materials Figure S2. Moreover, the CV curves of the $\mathrm{THMS} / 15 \mathrm{WO}_{3}$ exhibited the larger cathode and anode peak current densities, which reflects the fact that proton insertion/extraction into the host lattice is facilitated at a given applied potential. Furthermore, the onset potential of the cathodic current for the THMS $/ 15 \mathrm{WO}_{3}$ film is strongly shifted in the positive direction compared to the pure $\mathrm{WO}_{3}$ film; that is, insertion can be achieved at a considerably low applied voltage. The reason why the $\mathrm{THMS} / 15 \mathrm{WO}_{3}$ film showed superior electrochemical performance is discussed. As we know, the electrochemical performance of the electrochromic film is highly depended on the structure and composition. The incorporation of THMSs in $\mathrm{WO}_{3}$ film could endow the composite film with porous structure, which offer an easy path to charge transfer and diffusion processes of ions. For example, when the weight ratio of $\mathrm{Na}_{2} \mathrm{WO}_{4} \cdot 2 \mathrm{H}_{2} \mathrm{O}$ :THMSs was kept beyond 10:1, the prepared $\mathrm{THMS} / \mathrm{WO}$ composite films presented obviously porous structure (Figure 5A,C and Figure 3C). On the other hand, the incorporation of THMSs will hinder the oxidation-reduction of PTA on the surface of the FTO substrate and decrease the electroactive area of the composite film. This is quite obvious when the weight ratio of $\mathrm{Na}_{2} \mathrm{WO}_{4} \cdot 2 \mathrm{H}_{2} \mathrm{O}$ :THMSs was kept at 5:1. The resultant THMS/ $\mathrm{WO}_{3}$ composite film presented as compact $\mathrm{WO}_{3}$ film, as shown in Figure 5E. Thus, there exists optimal weight ratio of $\mathrm{Na}_{2} \mathrm{WO}_{4} \cdot 2 \mathrm{H}_{2} \mathrm{O}$ :THMSs of 15:1 to achieve THMS $/ \mathrm{WO}_{3}$ composite film with the best electrochemical performance from a trade-off between these two contradictory effects.
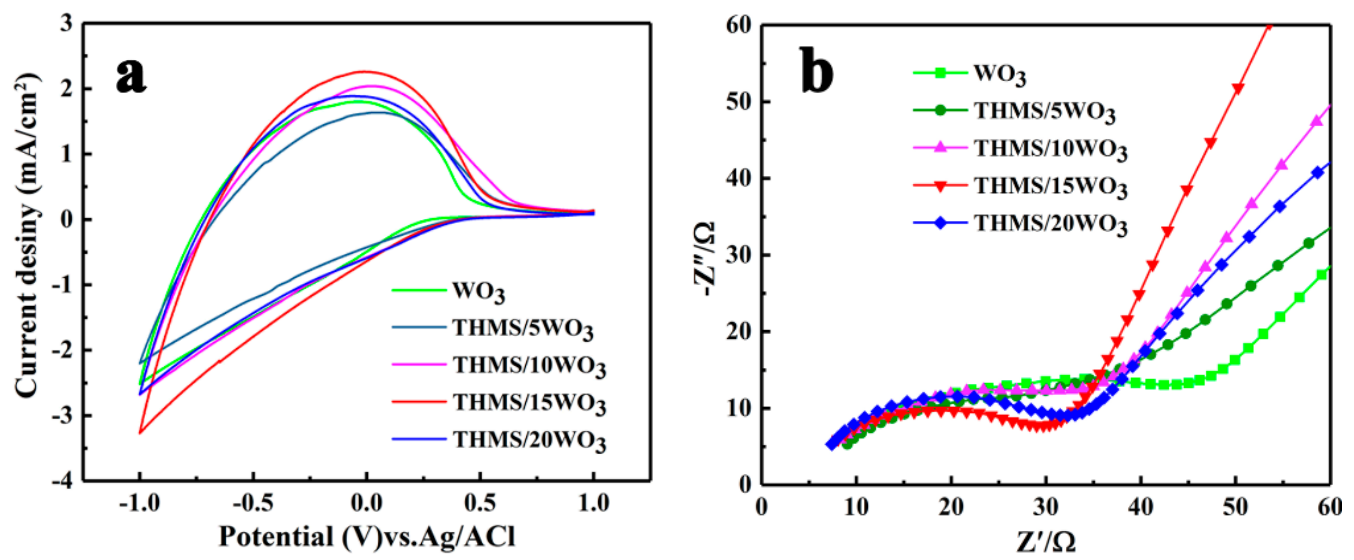

Figure 6. (a) The 5th CV curves of $\mathrm{WO}_{3}$ and $\mathrm{THMS} / \mathrm{WO}_{3}$ hybrid films at a scan rate of $50 \mathrm{mV} \mathrm{s}^{-1}$, and (b) the Nyquist plots of $\mathrm{WO}_{3}$ and $\mathrm{THMS} / \mathrm{WO}_{3}$ hybrid films.

The electric resistance is another important parameter to assess the electrochemical performance of electrochromic materials [49]. Thus, we further compared the resistance of the $\mathrm{WO}_{3}$ and $\mathrm{THMS} / \mathrm{WO}$ film electrodes by EIS measurements, which were conducted by applying an AC voltage of $5 \mathrm{mV}$ in a frequency range of $0.05 \mathrm{~Hz}$ to $100 \mathrm{kHz}$ at their bleached state (about $0.5 \mathrm{~V}$ vs. Ag/AgCl). Figure 6b showed the Nyquist plots of $\mathrm{WO}_{3}$ and $\mathrm{THMS} / \mathrm{WO}_{3}$ hybrid films. As shown, all the plots contained a semicircle at high-frequency represented the charge-transfer impedance on the electrode/electrolyte 
interface, and a straight line in the low frequency region correlated with ion diffusion process within the electrode. The THMS/15 $\mathrm{WO}_{3}$ hybrid films exhibited the smallest semicircle suggesting the lowest charge transfer resistance, and a straight line close to the theoretical vertical line implying the high ion diffusion rate.

To get a quantitative comparison of the ion diffusion efficiency in the $\mathrm{WO}_{3}$ and $\mathrm{THMS} / \mathrm{WO}_{3}$ film electrodes, the $\mathrm{CV}$ curves of the five films at different scan rates ranging from 10 to $100 \mathrm{mVs}^{-1}$ were measured. The CV curves are shown in Supplementary Materials Figure S3. The peak current $I_{p}$ (Amperes), during anodic scans at different scanning rates was used to extract the diffusion coefficient $D\left(\mathrm{~cm}^{2} \mathrm{~s}^{-1}\right)$ of $\mathrm{Li}^{+}$in the electrode, which could be calculated by employing the Randles-Sevcik equation (Equation (1)):

$$
I_{p}=2.71 \times 10^{5} A C n^{3 / 2} D^{1 / 2} v^{1 / 2}
$$

where $D$ was the diffusion coefficient of $\mathrm{Li}^{+}$ions, $v$ was the scan rate, $n$ was the number of electrons and it was assumed to be $1, A$ was the interface between the electrolyte and the active material, $C$ was the concentration of active ions in the electrolyte solution. The calculated diffusion coefficients of the five films were summarized in Table 1 . As shown, the THMS $/ 15 \mathrm{WO}_{3}$ hybrid film exhibited the highest $D$ value $\left(1.16 \times 10^{-6} \mathrm{~cm}^{2} \mathrm{~s}^{-1}\right)$, which was about 1.3 times higher than that of the pure $\mathrm{WO}_{3}$ $\left(8.82 \times 10^{-7} \mathrm{~cm}^{2} \mathrm{~s}^{-1}\right)$.

Table 1. Various parameters of $\mathrm{WO}_{3}$ and $\mathrm{THMS} / \mathrm{WO}_{3}$ hybrid films.

\begin{tabular}{|c|c|c|c|c|c|}
\hline \multirow{2}{*}{ Sample } & \multirow{2}{*}{$\begin{array}{l}\text { Diffusion } \\
\text { Coefficient } \\
\left(\mathrm{cm}^{2} \mathrm{~s}^{-1}\right)\end{array}$} & \multicolumn{2}{|c|}{ Switching Time } & \multirow{2}{*}{$\begin{array}{c}\text { Coloration Efficiency } \\
\left(\mathrm{cm}^{2} \mathrm{C}^{-1}\right) \\
\lambda=700 \mathrm{~nm}\end{array}$} & \multirow{2}{*}{$\begin{array}{c}\text { Modulation Rang of } \\
\text { the Transmittance }(\%) \\
\lambda=700 \mathrm{~nm}\end{array}$} \\
\hline & & $t_{\mathrm{c}}(\mathrm{s})$ & $t_{\mathrm{b}}(\mathrm{s})$ & & \\
\hline $\mathrm{WO}_{3}$ & $8.82 \times 10^{-7}$ & 19.15 & 14.23 & 46.84 & 34.10 \\
\hline $\mathrm{THMS} / 5 \mathrm{WO}_{3}$ & $7.85 \times 10^{-7}$ & 15.68 & 12.27 & 41.17 & 32.49 \\
\hline THMS $/ 10 \mathrm{WO}_{3}$ & $9.67 \times 10^{-7}$ & 13.86 & 14.19 & 68.86 & 48.77 \\
\hline THMS $/ 15 \mathrm{WO}_{3}$ & $1.16 \times 10^{-6}$ & 14.50 & 11.83 & 88.84 & 52.00 \\
\hline THMS/20WO 3 & $6.09 \times 10^{-7}$ & 14.06 & 14.22 & 58.62 & 37.77 \\
\hline
\end{tabular}

\subsubsection{Optical Performances}

The optical properties of $\mathrm{WO}_{3}$ and $\mathrm{THMS} / \mathrm{WO}_{3}$ hybrid films were measured after the film electrodes had been subjected to $\mathrm{CV}$ testing for 10 cycles in $1 \mathrm{M} \mathrm{LiClO}_{4} / \mathrm{PC}$. The transmittance of the samples at the colored and bleached states by applying step voltages of $-1 \mathrm{~V}$ and $1 \mathrm{~V}$ (vs. $\mathrm{Ag} / \mathrm{AgCl}$ ) for $40 \mathrm{~s}$, respectively, were recorded over a wavelength region from 300 to $1600 \mathrm{~nm}$ (Figure 7a). During cycling, the color of all the film changed reversibly from transparent to deep blue along with reversible surface redox reactions. The switching mechanism could be described by Equation (2):

$$
\mathrm{WO}_{3}+y \mathrm{Li}^{+}+y \mathrm{e}^{-} \leftrightarrow \mathrm{Li}_{y} \mathrm{WO}_{3}
$$

where $W(\mathrm{~V})$ was in blue color and $W(\mathrm{VI})$ was transparent. As shown in Figure 7a, all the hybrid films exhibited the large transmittance modulation range (transmittance contrast in bleached and colored states) at both VIS and NIR regions. The transmittance spectra of the samples at open circuit potential were shown in Figure $7 \mathrm{~b}$. At open circuit, potential of prepared $\mathrm{WO}_{3}$ and $\mathrm{THMS} / \mathrm{WO}_{3}$ hybrid films were in blue color with low transmittance of VIS and NIR radiations. We chose the wavelength at $700 \mathrm{~nm}$ as a typical example to make a quantitative study on the modulation ranges of the $\mathrm{THMS}_{\mathrm{WOO}}$ hybrid films. The modulation ranges $(\Delta T)$ of the transmittance $\left(\Delta T=T_{b}-T_{c}\right.$, where $T_{b}$ and $T_{c}$ denoted as transmittance in bleached and colored states, respectively) for the $\mathrm{WO}_{3}$ and $\mathrm{THMS} / \mathrm{WO}_{3}$ hybrid films at $700 \mathrm{~nm}$ were given in Table 1 . The modulation range of the transmittance could reach up to $32.49 \%, 48.77 \%, 52.00 \%$ and $37.77 \%$ at $700 \mathrm{~nm}$ for the $\mathrm{THMS} / 5 \mathrm{WO}_{3}, \mathrm{THMS} / 10 \mathrm{WO}_{3}, \mathrm{THMS} / 5 \mathrm{WO}_{3}$ and THMS $/ 20 \mathrm{WO}_{3}$ hybrid films, respectively. While the pure $\mathrm{WO}_{3}$ film only exhibited $34.10 \%$ at $700 \mathrm{~nm}$. The THMS $/ 15 \mathrm{WO}_{3}$ film showed the highest optical contrasts at $700 \mathrm{~nm}$. 

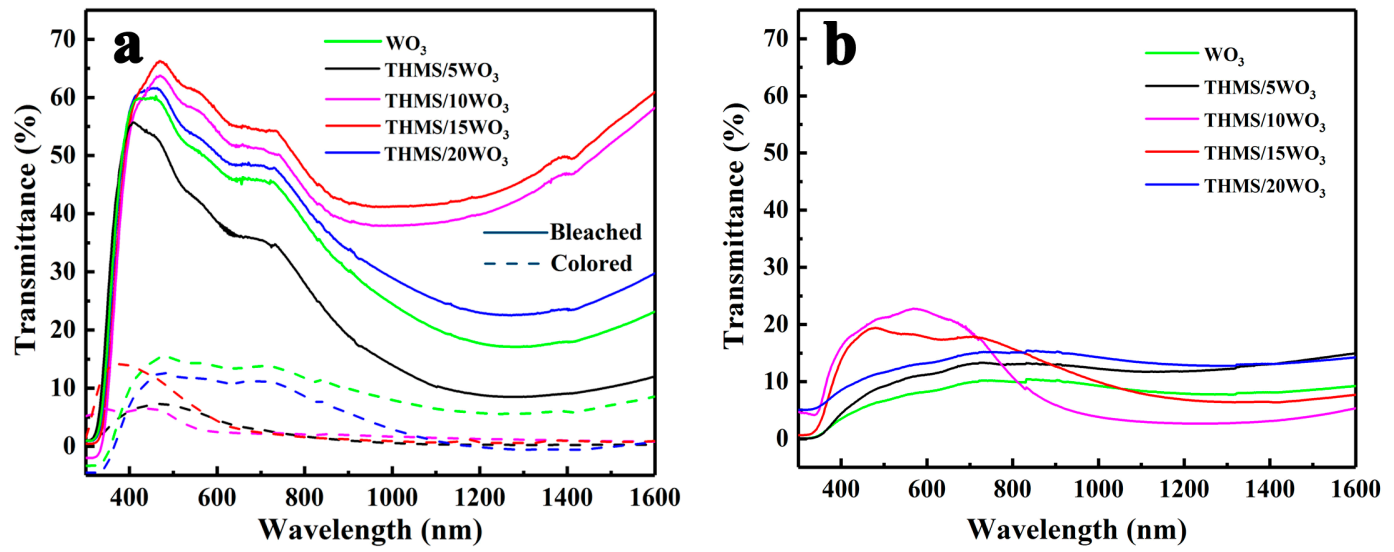

Figure 7. (a) The optical transmittance spectra of the $\mathrm{WO}_{3}$ and $\mathrm{THMS} / \mathrm{WO}_{3}$ hybrid films in the wavelength range of 300-1600 nm under applying alternate potentials of $-1 \mathrm{~V}$ and $1 \mathrm{~V}$; (b) the optical transmittance spectra of the $\mathrm{WO}_{3}$ and $\mathrm{THMS} / \mathrm{WO}_{3}$ hybrid films at open circuit potential.

The switching time is another crucial parameter that reflects the electrochromic property of the materials [50]. The switching characteristics of the pure $\mathrm{WO}_{3}$ and $\mathrm{THMS} / \mathrm{WO}_{3}$ hybrid films were investigated by $\mathrm{CA}$ and the corresponding in situ transmittance at $700 \mathrm{~nm}$ during continuous double potentiostatic measurements between $-1 \mathrm{~V}$ and $1 \mathrm{~V}$ at a time interval of $40 \mathrm{~s}$, as shown in Figure 8a,b. The values of $t_{c}$ and $t_{b}\left(t_{c}\right.$ and $t_{b}$ denotes as the colored time and the bleached time, respectively) for all the films were given in Table 1 . As shown, for the THMSs incorporated THMS/ $/ \mathrm{WO}_{3}$ hybrid films, the switching speed for full bleached and colored was faster than that of pure $\mathrm{WO}_{3}$ film. This may be attributed to the porous structure of the THMS $/ \mathrm{WO}_{3}$ hybrid films. Synthetically, comparison showed that the THMS $/ 15 \mathrm{WO}_{3}$ hybrid films exhibited the best switching characteristics with $t_{c}$ of $14.50 \mathrm{~s}$ and $t_{b}$ of $11.83 \mathrm{~s}$. Based on the transmittance of the electrochromic film in bleached and colored states (Figure $8 \mathrm{a}, \mathrm{b}$ ), the coloration efficiency of electrochromic film, which is defined as the change in optical density $(\triangle O D)$ resulting from the charge density $(\Delta Q)$ inserted into (or extracted from) the electrochromic material, can be calculated according to Equation (3).

$$
C E=\Delta O D / \Delta Q=\log \left(T_{b} / T_{c}\right) / \Delta Q
$$

where $T_{b}$ and $T_{c}$ refer to the transmittance of the electrochromic film in bleached and colored states, respectively. Figure $8 \mathrm{c}$ showed the plots of $\triangle O D$ at a wavelength of $700 \mathrm{~nm}$ vs. the inserted charge density for the oxides during the coloration process. The slope of the line fitting the linear region of the curve represented the coloration efficiency of the electrochromic films. The coloration efficiency value of pure $\mathrm{WO}_{3}$ film was calculated to be $46.84 \mathrm{~cm}^{2} \mathrm{C}^{-1}$ at $700 \mathrm{~nm}$, while the coloration efficiency value for THMS $/ 5 \mathrm{WO}_{3}, \mathrm{THMS} / 10 \mathrm{WO}_{3}, \mathrm{THMS} / 15 \mathrm{WO}_{3}$, and $\mathrm{THMS} / 20 \mathrm{WO}_{3}$ were $41.17,68.86$, 88.84 and $58.62 \mathrm{~cm}^{2} \mathrm{C}^{-1}$, respectively. Clearly, the THMS $/ 15 \mathrm{WO}_{3}$ hybrid film possessed the highest coloration efficiency. 

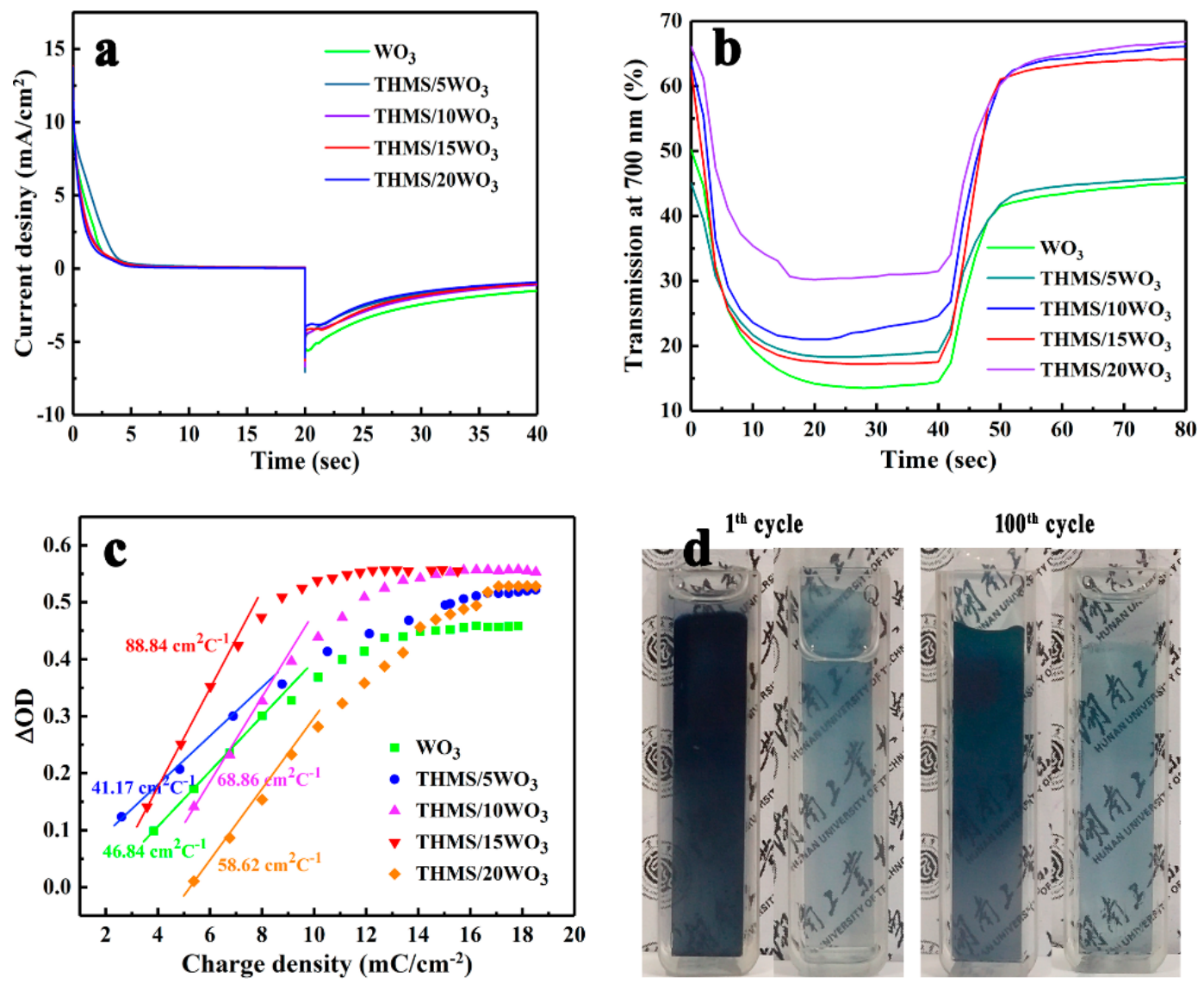

Figure 8. (a) the CA curves of the electrochromic films during continuous double potentiostatic measurements between $-1 \mathrm{~V}$ and $1 \mathrm{~V}$ with at time interval of $40 \mathrm{~s}$, (b) the corresponding in situ transmittance curves at $700 \mathrm{~nm}$ wavelength, (c) the optical density of $\mathrm{THMS} / \mathrm{WO}_{3}$ and pure $\mathrm{WO}_{3}$ films as a function of the charge density at $700 \mathrm{~nm}$, and (d) Photographs of the colored and bleached states of $\mathrm{THMS} / 15 \mathrm{WO}_{3}$ hybrid film at 1 th redox cycle and after 100 th redox cycles.

The above discussions have demonstrated that the THMS $/ 15 \mathrm{WO}_{3}$ hybrid film exhibited the most excellent electrochromic properties. Finally, the electrochromic stability of the THMS $/ 15 \mathrm{WO}_{3}$ hybrid film was checked by the comparison of the digital photo of the hybrid film at colored and bleached state before and after 100 times of redox cycles. The digital photos are shown in Figure 8d. As shown, the THMS $/ 15 \mathrm{WO}_{3}$ hybrid film still displayed a deep blue color at colored state and nearly transparent at the bleached state after 100 times of redox cycles, indicating the good electrochromic stability of the $\mathrm{THMS} / 15 \mathrm{WO}_{3}$ hybrid film. Therefore, we obtained an excellent electrochromic $\mathrm{THMS} / \mathrm{WO}_{3}$ hybrid film with good optical modulation, high coloration efficiency, and excellent cycling stability by keeping the weight ratio of $\mathrm{Na}_{2} \mathrm{WO}_{4} \cdot 2 \mathrm{H}_{2} \mathrm{O}$ (precursor of $\mathrm{WO}_{3}$ ):THMSs at 15:1. These properties endowed them to be effective candidates in various applications, such as large area information displays, rear-view mirrors for automobiles, thermal control of spacecraft and military camouflage.

\section{Conclusions}

In summary, we reported the successful fabrication of $\mathrm{THMS} / \mathrm{WO}_{3}$ hybrid film by electrochemical deposition method. The incorporation of THMSs in $\mathrm{WO}_{3}$ film resulted in the hybrid film with porous surface structure, which significantly increase the surface area of the hybrid film. It is demonstrated that the content of THMSs in the THMS/ $\mathrm{WO}_{3}$ hybrid film plays an important role on the morphology and electrochromic property of the hybrid film. We obtained an excellent electrochromic THMS $/ \mathrm{WO}_{3}$ hybrid film with good optical modulation $(52.00 \%$ at $700 \mathrm{~nm})$, high coloration efficiency $\left(88.84 \mathrm{~cm}^{2} \mathrm{C}^{-1}\right.$ at $700 \mathrm{~nm}$ ), and excellent cycling stability by keeping the weight ratio of $\mathrm{Na}_{2} \mathrm{WO}_{4} \cdot 2 \mathrm{H}_{2} \mathrm{O}$ (precursor 
of $\mathrm{WO}_{3}$ ):THMSs at 15:1. The outstanding electrochromic performances of the porous $\mathrm{THMS} / \mathrm{WO}_{3}$ hybrid film were mainly attributed to the porous surface structure, and proper amount of Ti-doping improved the electric conductivity of the hybrid film, which facilitates the charge-transfer, promotes the electrolyte infiltration and alleviates the expansion of the film during $\mathrm{Li}^{+}$insertion. We envision that the as-prepared THMS/ $/ \mathrm{WO}_{3}$ hybrid film will have great potential application in architecture, aerospace, information storage and artificial intelligence fields.

Supplementary Materials: The following are available online at http:/www.mdpi.com/2079-4991/9/12/1795/s1. Electronic supplementary information (ESI) available, including EDXS of Ti elemental, the CV curves of the pure $\mathrm{WO}_{3}, \mathrm{THMS} / 15 \mathrm{WO}_{3}$ and $\mathrm{HMS} / 15 \mathrm{WO}_{3}$ films at a scan rate of $50 \mathrm{mV} \mathrm{s}{ }^{-1}$ and the $\mathrm{CV}$ curves of the pure $\mathrm{WO}_{3}$ and $\mathrm{THMS} / \mathrm{WO}_{3}$ hybrid films at different scan rates.

Author Contributions: Funding acquisition, J.D. and L.X.; experiment design, Z.Z. and L.Z.; data collection, Y.S., L.Y., S.X. and L.X.; formal analysis, Y.S., S.L., and J.D.; writing-original draft preparation, S.L., and J.D.; writing—results and discussion, Y.S.; writing—review and editing, J.D.; visualization L.X.; project administration J.D.

Funding: This research received no external funding.

Acknowledgments: The financial support by the National Science Foundation of China (51974116 and 51874128) is gratefully acknowledged.

Conflicts of Interest: The authors declared no competing financial interest.

\section{References}

1. Granqvist, C.G.; Arvizu, M.A.; Bayrak Pehlivan, I.; Qu, H.Y.; Wen, R.T.; Niklasson, G.A. Electrochromic materials and devices for energy efficiency and human comfort in buildings: A critical review. Electrochim. Acta 2018, 259, 1170-1182. [CrossRef]

2. Eh, A.L.-S.; Lin, M.-F.; Cui, M.; Cai, G.; Lee, P.S. A copper-based reversible electrochemical mirror device with switchability between transparent, blue, and mirror states. J. Mater. Chem. C 2017, 5, 6547-6554. [CrossRef]

3. Lin, L.; Cheng, C.-P.; Teng, T.-P. Electrodeposition-Based fabrication and characteristics of tungsten trioxide thin film. J. Nanomater. 2016, 2016, 1-12. [CrossRef]

4. Shen, L.; Du, L.; Tan, S.; Zang, Z.; Zhao, C.; Mai, W. Flexible electrochromic supercapacitor hybrid electrodes based on tungsten oxide films and silver nanowires. Chem. Commun. 2016, 52, 6296-6299. [CrossRef]

5. Dulgerbaki, C.; Oksuz, A.U. Fabricating polypyrrole/tungsten oxide hybrid based electrochromic devices using different ionic liquids. Polym. Adv. Technol. 2016, 27, 73-81. [CrossRef]

6. Xie, S.; Gong, G.; Song, Y.; Tan, H.; Zhang, C.; Li, N.; Zhang, Y.; Xu, L.; Xu, J.; Zheng, J. Design of novel lanthanide-doped core-shell nanocrystals with dual up-conversion and down-conversion luminescence for anti-counterfeiting printing. Dalton Trans. 2019, 48, 6971-6983. [CrossRef]

7. Malik, N.; Elool Dov, N.; de Ruiter, G.; Lahav, M.; van der Boom, M.E. On-Surface self-assembly of stimuli-responsive metallo-organic films: Automated ultrasonic spray-coating and electrochromic devices. ACS Appl. Mater. Interfaces 2019, 11, 22858-22868. [CrossRef]

8. Fang, H.; Zheng, P.; Ma, R.; Xu, C.; Yang, G.; Wang, Q.; Wang, H. Multifunctional hydrogel enables extremely simplified electrochromic devices for smart windows and ionic writing boards. Mater. Horiz. 2018, 5, 1000-1007. [CrossRef]

9. Kim, H.N.; Yang, S. Responsive smart windows from nanoparticle-polymer composites. Adv. Funct. Mater. 2019, 1902597. [CrossRef]

10. Cai, G.; Cui, M.; Kumar, V.; Darmawan, P.; Wang, J.; Wang, X. Ultra-large optical modulation of electrochromic porous $\mathrm{WO}_{3}$ film and the local monitoring of redox activity. Chem. Sci. 2016, 7, 1373-1382. [CrossRef]

11. Shi, Y.; Liu, S.; Zhang, Y.; Sun, M.; Tang, K.; Cui, J.; Shu, X.; Wang, Y.; Liu, J.; Wu, Y. Construction of $\mathrm{WO}_{3} /$ Ti-doped $\mathrm{WO}_{3}$ bi-layer nanopore arrays with superior electrochromic and capacitive performances. Tungsten 2019, 1, 236-244. [CrossRef]

12. Yang, Y.; Du, X.; An, X.; Ding, S.; Liu, F.; Zhang, Z. Potential-induced reversible uptake/release of perchlorate from wastewater by polypyrrole@CoNi-layered double hydroxide modified electrode with proton-ligand effect. J. Colloid Interface Sci. 2018, 523, 159-168. [CrossRef] [PubMed] 
13. Xiong, S.; Jia, P.; Mya, K.Y.; Ma, J.; Boey, F.; Lu, X. Star-like polyaniline prepared from octa (aminophenyl) silsesquioxane: Enhanced electrochromic contrast and electrochemical stability. Electrochim. Acta. 2008, 53, 3523-3530. [CrossRef]

14. Xu, J.; Feng, Y.; Wu, Y.; Li, Y.; Ouyang, M.; Zhang, X.; Wang, Y.; Wang, Y.; Xu, L. Noninvasive monitoring of bone regeneration using $\mathrm{NaYF}_{4}: \mathrm{Yb}^{3+}, \mathrm{Er}^{3+}$ upconversion hollow microtubes supporting PLGA-PEG-PLGA hydrogel. React. Funct. Polym. 2019, 143, 104333. [CrossRef]

15. Havinga, E.; Van Pelt, P. Intramolecular charge transfer, studied by electrochromism of organic molecules in polymer matrices. Mol. Cryst. Liq. Cryst. 1979, 52, 145-155. [CrossRef]

16. Zhang, Y.-M.; Wang, X.; Zhang, W.; Li, W.; Fang, X.; Yang, B. A single-molecule multicolor electrochromic device generated through medium engineering. Light-Sci. Appl. 2015, 4, e249. [CrossRef]

17. Zhao, L.; Su, G.; Liu, W.; Cao, L.; Wang, J.; Dong, Z. Optical and electrochemical properties of Cu-doped NiO films prepared by electrochemical deposition. Appl. Surf. Sci. 2011, 257, 3974-3979. [CrossRef]

18. Liu, Y.; Jia, C.; Wan, Z.; Weng, X.; Xie, J.; Deng, L. Electrochemical and electrochromic properties of novel nanoporous $\mathrm{NiO} / \mathrm{V}_{2} \mathrm{O}_{5}$ hybrid film. Sol. Energy Mater. Sol. Cells 2015, 132, 467-475. [CrossRef]

19. Yuan, G.; Hua, C.; Khan, S.; Jiang, S.; Wu, Z.; Liu, Y. Improved electrochromic performance of $\mathrm{WO}_{3}$ films with size controlled nanorods. Electrochim. Acta 2018, 260, 274-280. [CrossRef]

20. Atak, G.; Coşkun, Ö.D. Fabrication of an all solid-state electrochromic device using zirconium dioxide as an ion-conducting layer. Thin Solid Films 2018, 664, 70-78. [CrossRef]

21. Costa, C.; Pinheiro, C.; Henriques, I.; Laia, C.A. Inkjet printing of sol-gel synthesized hydrated tungsten oxide nanoparticles for flexible electrochromic devices. ACS Appl. Mater. Interfaces 2012, 4, 1330-1340. [CrossRef] [PubMed]

22. Wang, Y.; Meng, Z.; Chen, H.; Li, T.; Zheng, D.; Xu, Q. Pulsed electrochemical deposition of porous $\mathrm{WO}_{3}$ on silver networks for highly flexible electrochromic devices. J. Mater. Chem. C 2019, 7, 1966-1973. [CrossRef]

23. Baloukas, B.; Lamarre, J.M.; Martinu, L. Electrochromic interference filters fabricated from dense and porous tungsten oxide films. Sol. Energy Mater. Sol. Cells 2011, 95, 807-815. [CrossRef]

24. Tuna, Ö.; Sezgin, A.; Budakoğlu, R.; Türküz, S.; Parlar, H. Electrochromic properties of tungsten trioxide $\left(\mathrm{WO}_{3}\right)$ layers grown on ITO/glass substrates by magnetron sputtering. Vacuum 2015, 120, 28-31. [CrossRef]

25. Zhou, K. The Mechanism of Trapped Ions Eroding the Electrochromic Performances of $\mathrm{WO}_{3}$ Thin Films. Int. J. Electrochem. Sci. 2018, 13, 7335-7346. [CrossRef]

26. Wu, C.-L.; Lin, C.-K.; Wang, C.-K.; Wang, S.-C.; Huang, J.-L. Annealing induced structural evolution and electrochromic properties of nanostructured tungsten oxide films. Thin Solid Films 2013, 549, 258-262. [CrossRef]

27. More, A.J.; Patil, R.S.; Dalavi, D.S.; Mali, S.S.; Hong, C.K.; Gang, M.G.; Kim, J.H.; Patil, P.S. Electrodeposition of nano-granular tungsten oxide thin films for smart window application. Mater. Lett. 2014, 134, $298-301$. [CrossRef]

28. Han, J.; Ko, K.-W.; Sarwar, S.; Lee, M.-S.; Park, S.; Hong, S.; Han, C.-H. Enhanced electrochromic properties of $\mathrm{TiO}_{2}$ nanocrystal embedded amorphous $\mathrm{WO}_{3}$ films. Electrochim. Acta 2018, 278, 396-404. [CrossRef]

29. Li, N.; Wei, P.; Yu, L.; Ji, J.; Zhao, J.; Gao, C. Dynamically switchable multicolor electrochromic films. Small 2019, 15, e1804974. [CrossRef]

30. Dalavi, D.S.; Devan, R.S.; Patil, R.A.; Patil, R.S.; Ma, Y.-R.; Sadale, S.B. Efficient electrochromic performance of nanoparticulate $\mathrm{WO}_{3}$ thin films. J. Mater. Chem. C 2013, 1, 3722-3728. [CrossRef]

31. Xie, Z.; Zhang, Q.; Liu, Q.; Zhai, J.; Diao, X. Enhanced electrochromic performance of 2D grid-structured $\mathrm{WO}_{3}$ thin films. Thin Solid Films 2018, 653, 188-193. [CrossRef]

32. Zhang, J.; Tu, J.P.; Cai, G.F.; Du, G.H.; Wang, X.L.; Liu, P.C. Enhanced electrochromic performance of highly ordered, macroporous $\mathrm{WO}_{3}$ arrays electrodeposited using polystyrene colloidal crystals as template. Electrochim. Acta 2013, 99, 1-8. [CrossRef]

33. Yan, L.; Yu, J.; Zhong, Y.; Gu, Y.; Ma, Y.; Li, W. Influence of scanning on nano crystalline $\beta$-Ti alloys fabricated by selective laser melting and their applications in biomedical science. J. Nanosci. Nanotechnol. 2020, 20, 1605-1612. [CrossRef] [PubMed]

34. Zhou, H.; Zhou, J.; Wang, T.; Zeng, J.; Liu, L.; Jian, J. In-situ preparation of silver salts/collagen fiber hybrid composites and their photocatalytic and antibacterial activities. J. Hazard. Mater. 2018, 359, 274-280. [CrossRef] 
35. Ling, H.; Lu, J.; Phua, S.; Liu, H.; Liu, L.; Huang, Y. One-pot sequential electrochemical deposition of multilayer poly(3,4-ethylenedioxythiophene): Poly(4-styrenesulfonic acid)/tungsten trioxide hybrid films and their enhanced electrochromic properties. J. Mater. Chem. A 2014, 2, 2708-2717. [CrossRef]

36. Song, X.C.; Zheng, Y.F.; Ma, R.; Yin, H.Y. Electrodeposition of poly(3-chlorothiophene) film on $\mathrm{WO}_{3}$ surfaces in an ionic liquid. J. Macromol. Sci. B 2012, 51, 1080-1088. [CrossRef]

37. Fu, C.; Foo, C.; Lee, P.S. One-step facile electrochemical preparation of $\mathrm{WO}_{3} /$ graphene nanocomposites with improved electrochromic properties. Electrochim. Acta 2014, 117, 139-144. [CrossRef]

38. Cai, G.F.; Zhou, D.; Xiong, Q.Q.; Zhang, J.H.; Wang, X.L.; Gu, C.D. Efficient electrochromic materials based on $\mathrm{TiO}_{2} @ \mathrm{WO}_{3}$ core/shell nanorod arrays. Sol. Energy Mater. Sol. Cells 2013, 117, 231-238. [CrossRef]

39. Acosta, D.R.; Magaña, C.; Hernández, F.; Ortega, J. Electrical, optical and electrochromic properties of Ti: $\mathrm{WO}_{3}$ thin films deposited by the pulsed chemical spray technique. Thin Solid Films 2015, 594, 207-214. [CrossRef]

40. Karuppasamy, A. Electrochromism and photocatalysis in dendrite structured Ti: $\mathrm{WO}_{3}$ thin films grown by sputtering. Appl. Surf. Sci. 2015, 359, 841-846. [CrossRef]

41. Barawi, M.; Veramonti, G.; Epifani, M.; Giannuzzi, R.; Sibillano, T.; Giannini, C.; Manca, M. A dual band electrochromic device switchable across four distinct optical modes. J. Mater. Chem. A 2018, 6, 10201-10205. [CrossRef]

42. Cai, G.-F.; Wang, X.-L.; Zhou, D.; Zhang, J.-H.; Xiong, Q.-Q.; Gu, C.-D. Hierarchical structure Ti-doped $\mathrm{WO}_{3}$ film with improved electrochromism in visible-infrared region. RSC Adv. 2013, 3, 6896-6905. [CrossRef]

43. Du, G.; Song, Y.; Li, N.; Xu, L.; Tong, C.; Feng, Y.; Chen, T.; Xu, J. Cage-like hierarchically mesoporous hollow silica microspheres templated by mesomorphous polyelectrolyte-surfactant complexes for noble metal nanoparticles immobilization. Colloid. Surface. A 2019, 575, 129-139. [CrossRef]

44. Shi, C.; Wang, W.; Liu, N.; Xu, X.; Wang, D.; Zhang, M. Low temperature oxidative desulfurization with hierarchically mesoporous titaniumsilicate Ti-SBA-2 single crystals. Chem. Commun. 2015, 51, 11500-11503. [CrossRef]

45. Tan, H.; Gong, G.; Xie, S.; Song, Y.; Zhang, C.; Li, N.; Zhang, D.; Xu, L.; Xu, J.; Zheng, J. Upconversion nanoparticles@carbon dots@meso- $\mathrm{SiO}_{2}$ sandwiched core-shell nanohybrids with tunable dual-mode luminescence for 3D anti-counterfeiting barcodes. Langmuir 2019, 35, 11503-11511. [CrossRef]

46. Li, Y.; McMaster, W.A.; Wei, H.; Chen, D.; Caruso, R.A. Enhanced electrochromic properties of $\mathrm{WO}_{3}$ nanotree-like structures synthesized via a two-step solvothermal process showing promise for electrochromic window application. ACS Appl. Nano Mater. 2018, 1, 2552-2558. [CrossRef]

47. Gong, G.; Song, Y.; Tan, H.; Xie, S.; Zhang, C.; Xu, L.; Xu, J.; Zheng, J. Design of core/active-shell $\mathrm{NaYF}_{4}: \mathrm{Ln}^{3+} @ \mathrm{NaYF}_{4}: \mathrm{Yb}^{3+}$ nanophosphors with enhanced red-green-blue upconversion luminescence for anti-counterfeiting printing. Compos. Part B-Eng. 2019, 179, 107504. [CrossRef]

48. Zhan, Y.; Tan, M.R.J.; Cheng, X.; Tan, W.M.A.; Cai, G.F.; Chen, J.W. Ti-Doped $\mathrm{WO}_{3}$ synthesized by a facile wet bath method for improved electrochromism. J. Mater. Chem. C 2017, 5, 9995-10000. [CrossRef]

49. Das, A.K.; Paria, S.; Maitra, A.; Halder, L.; Bera, A.; Bera, R. Highly rate capable nanoflower-like NiSe and $\mathrm{WO}_{3} @ P P y$ composite electrode materials toward high energy density flexible all-solid-state asymmetric supercapacitor. ACS Appl. Electron. Mater. 2019, 1, 977-990. [CrossRef]

50. Zhang, W.; Wang, X.; Wang, Y.; Yang, G.; Gu, C.; Zheng, W. Bio-inspired ultra-high energy efficiency bistable electronic billboard and reader. Nat. Commun. 2019, 10, 1559. [CrossRef]

(C) 2019 by the authors. Licensee MDPI, Basel, Switzerland. This article is an open access article distributed under the terms and conditions of the Creative Commons Attribution (CC BY) license (http://creativecommons.org/licenses/by/4.0/). 